'beloid', 'ovoid', 'pentagonoid' and the like. These revolutionary views were first put forward at the International Anthropological Congress at Moscow in 1893. Commenting some years later on the results of his researches on the Mediterranean race, Sergi said that he had followed the various peoples of the Mediterranean with their racial names in ancient and modern history, and had examined the ancient and modern skulls of the peoples of Iberia, Liguria, Central and Southern Italy, Greece, Asia Minor and Egypt, and among them all, from Spain to Hissarlik, he had found about a dozen forms of skull, and these were common to all, while the ancient cranial form invariably resembled the modern, whatever foreign influence might have intruded. Further, he maintained that these forms did not occur at all among other peoples of Europe, such as Celtic, Germanic and Finnic-a statement, be it said, which has been regarded by his critics as at least subject to qualification.

Sergi's great work, "Origine e Diffuzione della Stirpe mediterranea", which must be regarded as the crown of his labours, appeared in 1895. A German translation was published in 1897, and an English version appeared in 1901. This last contained so much additional matter as to constitute what was virtually a new work. It is of interest, and of indubitable importance in assessing Sergi's position, to bring "The Mediterranean Race" into relation with the anthropological thought of the time of its publication. Without in any way impugning Sergi's impartiality in viewing the facts, it may be said that he was inspired by a reaction against 'Germanism', the view then held in certain quarters that the early civilization of Europe, that is, the civilization of the Mediterranean, was duo to the impact on the peoples of that area of a tall, long-headed, fair race, identified with the Aryans, who were held to have originated in Northern Europe, and further, were said to be represented in the modern population by the Germans and their racial affinities. In reply to this last contention, Sergi argued that the Germans were not to be distinguished from Celts and Slavs with whom they had always been associated, and with whom they were often confused; while the long-headed fair peoples of northern Europe, the Reihengraber and Viking types, were of Mediterranean origin.

Sergi, in fact, maintained that the neolithic population of Europe and the Mediterranean area, the Mediterranean race, the North African peoples, and the long-headed population of Northern Europe were three offshoots, or varieties of one original Mediterranean, or Eur-African race, which had sprung from Africa, and of which the Mediterranean was the centre of dispersal. The Mediterranean culture, which had ultimately blossomed into the civilization of Greece and Rome, was entirely a product of this Mediterranean race, developing a seed which had been brought from Asia Minor. So far was this de. velopment from being the work of the Aryan speaking peoples, that it was they, the peoples of Asiatic, and not European, origin who, he maintained, had been the destroyers of that culture. It will be remembered that at the time this was written, Sergi had before him only the evidence of the so-called Mycenean age, and the Minoan civilization of Crote, which would have added strength to his a"gument, was as yet almost unknown.

Any attempt to estimate the value of Sergi's work and methods in the subsequent derelopment of anthropological studies must take into account at least two factors. Of these, one was the development at about the same time of the application of biometric methods to the study of man, which to a certain extent and with limitations rehabilitated anthropometric measurement as a means of observation ; and the second was the publication of Deniker's classification of the races of Europe (1897 and 1904) and Ripley's work "The Races of Europe" (1901), which following more nearly traditional methods of study, appeared to afford greater precision in working than Sergi's scheme. Sergi himself, though continuing to employ his method of inspection and classification of form throughout his life, later abandoned his extreme attitude towards craniometry; but his arguments, though not adopted in full by his fellow anthropologists, have secured in an increasing degree that reliance should be placed on observational study of the skull to bring out differences which are obscured by or escape measurement.

Of Sergi's later work, considerable though it is in volume, little need be said here. It never attained the international importance of his Mediterranean studies. In 1908 he published the results of an application of his theories to study of the relation of the Mediterranean race to the peoples of Europe generally, and later extended his published work to cover the field of the races of man as a whole, and the question of the origin and descent of man, where he turned to consider the geological and palæon. tological evidence bearing on anthropological studies. In this field his most important work is "L'Uomo", which appeared in 1911. That he maintained fully his mental vigour and flexibility to the end is demonstrated in a remarkable book "La più antica Umanità vivente" (1930), in which he skilfully interpreted the evidence of Rhodesian man in tracing a line of descent from Neanderthal man to representative types in modern races.

E. N. F.

\section{Dr. A. Daniell}

By the death of Dr. Alfred Daniell in Edinburgh on January 12, there passed one who had made a distinct mark in the world of science. Born at Llanelly eighty-three years ago, he early showed a bent towards educational attainment. In consequence, while still a boy, he was sent north to pursue his studies in the University of Edinburgh. Ho had a distinguished course in arts, medicine and science, obtaining many successes and distinctions, particularly in science. For a time he was lecturer in the Medical School. He also worked under Prof. (afterwards Lord) Lister in the old Royal Infirmary, where he had charge of the Out-patient Department. He was the author of the well-known "Text Book of the Principles of Physics" published by Messrs. Mac. millan and Co. so long ago as 1884 , and "Physics for 
Students of Medicine". These publications were successful, especially the former, which was translated into various foreign languages.

In 1886 Dr. Daniell became an advocate of the Scottish Bar, and in 1894 he sought a wider sphere, becoming an English barrister-in each case seeking to utilize his scientific attainments in his new pro. fession.

Dr. Daniell was faithful through life to his Alma Mater at Edinburgh, of which he became M.A., D.Sc., and LL.B. He took part in certain of its activities while health permitted. He was also a fellow of the Royal Society of Edinburgh.

The last twenty years of Dr. Daniell's long life were spent in Edinburgh. He was chiefly occupied in writing a new book called "Problems in Physics", which he was able to finish, but was not destined to see published. He also revised, and partly rewrote, his "Text Book". But for some time before his death, failing health greatly curtailed his activities.
WE regret to announce the following deaths :

The Right Hon. Sir Austen Chamberlain, K.G., P.C., Chancellor of the University of Reading since 1935 , and chairman of the Court of Governors of the London School of Hygiene and Tropical Medicine and of the Governing Body of the British Postgraduate Medical School, on March 16, aged seventy-three years.

Mr. A. Gallenkamp, founder of A. Gallenkamp and Co., Ltd., makers of laboratory equipment, on February 26, aged eighty-eight years.

Prof. A. Pictet, honorary fellow of the Chemical Society and formerly professor of organic chemistry in the University of Geneva, on March 12, aged eighty years.

Dr. Elihu Thomson, the well-known American electrical engineer, who received the Hughes Medal of the Royal Society in 1916, on March 13, aged eighty-three years.

\section{News and Views}

\section{Prof. T. C. Hodson}

THE announcement of the impending retirement of Prof. T. C. Hodson from the William Wyse chair of social anthropology in the University of Cambridge in September next will be received with regret by all who are interested in the advancement of studies in that branch of the science of man, not only within the University but also at large. When Prof. Hodson was placed in charge of this subject at first in 1926 as reader in ethnology and from 1932 as occupant of the chair which he now relinquishes, he brought to the teaching of a subject which, more than almost any other in the academic curriculum, demands breadth of view and a sense of realities, a wide and varied experience. This began after he had taken his degree at Queen's College, Oxford, with some years as a member of the Indian Civil Service stationed in Assam, and embraced service with the Indian forces during the Great War, and a period as principal of an ex-Service men's college, of which the curriculum had been strongly influenced by his faith in the educative and broadening influence of the point of view of the anthropologist in the approach to educational and cultural problems. It is in some sense a mitigation of the regret which will be felt at Prof. Hodson's retirement that his successor, who has also served in India, by experience and by conviction, is well qualified to continue the work which Prof. Hodson has always had most nearly at heart, in the firm belief that a knowledge of anthropology is the best and the most essential qualification in the administration of the affairs of the varied peoples of the British Empire.

\section{Social Anthropology at Cambridge}

Dr. John Henry Hutron, of St. John's College, Cambridge, who is to succeed Prof. T. C. Hodson, was educated at Chigwell School, and Worcester College, Oxford. Dr. Hutton was appointed lecturer in the Faculty of Archæology and Ethnology at Cambridge last year, on his retirement from the Indian Civil Service. He entered the Service in 1909, serving under the Government of Assam, and being awarded the honour of C.I.E. in 1920. In addition to his administrative duties, Dr. Hutton was responsible as honorary director for the ethnographic survey of the tribes of Assam, and himself produced two volumes, one on the Angami Nagas (1921) and one on the Sema Nagas (1929) in the series of monographs on the Naga tribes published under the auspices of the Assam Government. Dr. Hutton's abilities as an anthropologist and as an organizer of survey work in anthropology and demography were recognized when he was seconded from the service of the Assam Government to take charge of the Census of India, 1931. As superintendent of the Census, he wrote an introductory study of the ethnic problem involved in the composition of the population of India, summing up and analysing the evidence which has accrued since the publication of Sir H. H. Risley's Census of 1901 and calling for modification in the views then put forward. Reference was made to Dr. Hutton's work in Nature of September 5, 1936, p. 394. Mr. Gregory Bateson, of St. John's College, Cambridge, has been elected to the William Wyse studentship in social anthropology in the University of Cambridge for a period of three years. Mr. Bateson is the author 